\title{
Removal of copper from copper-contaminated river water and aqueous solutions using Methylobacterium extorquens modified Erzurum clayey soil
}

\author{
Neslihan Celebi ${ }^{*}$, Hayrunnisa Nadaroglu², Ekrem Kalkan ${ }^{3}$, Recep Kotan ${ }^{4}$ \\ Ataturk University, Erzurum, Turkey \\ ${ }^{1}$ Erzurum Vocational Training School, Department of Chemical Technology \\ ${ }^{2}$ Erzurum Vocational Training School, Department of Food Technology \\ ${ }^{3}$ Oltu Earth Sciences Faculty, Geological Engineering Department \\ ${ }^{4}$ Agriculture Faculty, Department of Plant Protection \\ *Corresponding author's e-mail: nes25@atauni.edu.tr
}

\begin{abstract}
Keywords: copper (II) removal, adsorption, erzurum clayey soil, Methylobacterium extorquens, modified clay, wastewater.

Abstract: The objective of this study was to investigate the possibility of using natural and bacteria-modified Erzurum clayey soil with Methylobacterium extorquens as an alternative to high cost commercial adsorbent materials for the removal of copper from aqueous solution. The copper concentrations in the samples of the polluted river water and $\mathrm{CuCl}_{2}$ solutions treated by the natural and bacteria-modified Erzurum clayey soil (ECS) have been determined by spectrophotometric method. Firstly, the surface of ECS was modified with M. extorquens and surface functionality was increased. Then, the adsorption of $\mathrm{Cu}$ (II) from solution phases was studied with respect to varying metal concentration, $\mathrm{pH}$, and temperature and agitation time. The maximum adsorption of $\mathrm{Cu}$ (II) for natural and bacteria-modified Erzurum clayey soil was observed at pH: 5.0. At different copper concentrations, copper adsorption analysis was performed on $1 \mathrm{~g}$ using clay soil or modified clay soil. Maximum adsorption of $\mathrm{Cu}$ (II) was obtained as 45.7 and $48.1 \mathrm{mg} \mathrm{g}^{-1}$ at initial concentration $(50 \mathrm{mg} / 50 \mathrm{~mL})$ and optimal conditions by natural and bacteria-modified clay soil, respectively. The copper concentration was decreased in the substantial amount of the leachates solutions of natural and bacteria-modified clay soil. Langmuir and Freundlich isotherms were used to describe the adsorption behavior of $\mathrm{Cu}$ (II) ions. The results showed that modified clay soil had a high level of adsorption capacity for copper ion. The various thermodynamic parameters such as $\Delta G^{\circ}, \Delta H^{\circ}$ and $\Delta S^{\circ}$ were analyzed to observe the nature of adsorption. The structural properties of the natural and bacteria-modified-ECS have been characterized by SEM, FTIR and XRD techniques. Consequently, it was concluded that the bacteria-modified clay soil could be successfully used for the removal of the copper ions from the aqueous solutions.
\end{abstract}

\section{Introduction}

Nowadays industrialization and urbanization in the world have led to an increase in ecological problems. Heavy metal pollution has become a serious threat for environment and it is non-biodegradable (Benaissa and Elouchdi 2007). Various toxic heavy metal ions discharged through different industrial activities constitute one of the major causes of water pollution. Heavy metal residues in contaminated habitats may accumulate in microorganisms, aquatic flora and fauna, which in turn, may enter the human food chain and result in health problems (Bhatnagara, et al. 2010)

Copper is known to be one of heavy metals and is widely used in many industries including metal cleaning and plating baths, paints and pigments, fertilizer, paper board, wood pulp, printed board circuit production, etc. ( Aksu and Isoglu 2005, Zhu et al. 2009). The higher concentration of copper will cause severe mucosal irritation and corrosion, widespread capillary damage, hepatic and renal damage, and central nervous system irritation followed by depression (Ahmad et al. 2009).

Copper metal ions are especially discharged from the industrial waste streams of metal cleaning and plating baths, pulp, paper, paperboard and wood, preservative-employing mills, the fertilizer industry, etc. Although copper is an essential metal for human life and health, it is potentially toxic like all heavy metals (Sarioglu et al. 2009, Ibrahim et al. 2009, Jaman et al. 2009). Copper ions are limited for environmental pollution, but the waste produced by copper-based industries with various toxic elements can pollute the environment (Nohut, et al. 1999, Nadaroglu, et al. 2010, Kalkan et al. 2012, Nadaroglu and Kalkan 2012).

In the water treatment process, adsorption process method is chosen using the low-cost adsorbents in the removal of heavy metal. This process has more techno-economic 
and environmental advantages such as cheapness, easy obtainability, efficiency of adsorption, and environmental friendliness associated with low-cost adsorbents than other water treatment techniques. Some low cost adsorbents have been investigated including modified clays (Bhattacharyya and Gupta 2008). But most of these investigated adsorbents did not support the expected efficiency of pollutant removal in terms of technicality, low stability, low mechanical strength, non-durability, and/or poor re-usability, thus limiting their potential for applications (Nadaroglu, et al. 2014, Wang et al. 2012, Kakitani et al. 2009, Sahan et al. 2010, Chen et al. 2011, Sarioglu et al. 2005). The aforementioned factors have led to the search for more efficient and lower cost adsorbents.

Among previously used removal techniques, adsorption process has been found as one of the most promising technologies in water pollution control in terms of cost, simplicity of design and operation. Activated carbon has undoubtedly been the most popular and widely used adsorbent in wastewater treatment applications throughout the world (Bansal and Goyal 2005) and has been successfully utilized for the removal of diverse types of pollutants including metal ions. However, the high capital and regeneration cost of the activated carbon limits its largescale applications for the removal of metals and other aquatic pollutants, which have encouraged researchers to look for lowcost alternative adsorbents (Dias et al. 2007).

Clay geological materials are low cost and readily available materials functioning as excellent cation exchangers, and have often been used in adsorption and catalysis. They play an important role in the environment acting as natural scavengers of pollutants through ion exchange or adsorption. Erzurum clayey soil is a natural material which is abundant in nature. It can be obtained directly from nature, and it can be used without any processing. For this reason Erzurum clayey soil is cheaper than other adsorbents (Kalkan and Yarbası 2013).

Synergistic combinations of clays and microorganisms (both of them are low cost adsorbents) have attracted much attention because of their growing properties. These synergistic combinations may gain better sorbent properties such as high cation exchange capacity, bleeding reduction, enhanced mechanical strength, increased pore size, and consequently higher adsorption efficiency, better stability and durability, re-usability, sometimes larger surface area, and even comparatively lower cost for water treatment.

The aim of this study was to examine the efficiency of natural and modified-ECS as adsorbent for the removal of copper ions from aqueous solutions. We wanted to determine whether this material might be cost-effective and be an alternative adsorbent that could replace the expensive resins now used for wastewater treatment. Erzurum clay soil was modified with $M$. extorquens and bacteria-modified ECS was carried out in this study in order to ascertain the above. The bacteria-modified sorbent obtained was tested for the removal of $\mathrm{Cu}$ (II), ions from aqueous solutions.

\section{Materials and method}

\section{Bacterial strains, culture conditions, media and treatments}

M. extorquens bacteria have the ability to produce bioplastics using different carbon sources. The general structure of bioplastics is polyhydroxyalkanoates (PHA). Thus, Erzurum clayey soil surface which is used as a sorbent was made rougher for adsorption. For this reason, M. extorquens bacteria were selected and the sorbent surface was modified by Erzurum clayey M. extorquens bacteria (Jan et al.1996). M. extorquens was grown on Nutrient Agar (NA) for routine use, and maintained in Nutrient Broth (NB) with $15 \%$ glycerol at $-80^{\circ} \mathrm{C}$ for long-term storage. For each experiment, a single colony was transferred to $500 \mathrm{~mL}$ flasks containing $\mathrm{NB}$, and grown aerobically in flasks on a rotating shaker (150 rpm) for $48 \mathrm{~h}$ at $27^{\circ} \mathrm{C}$ (Merck KGaA, Germany). M. extorquens suspension was then diluted in sterile distilled water to a final concentration of $10^{8} \mathrm{CFU} / \mathrm{mL}$, and the resulting suspensions were used to modify the Erzurum clayey soil.

\section{Adsorbent}

In this study, the ECS was used as adsorbent to remove copper ions from aqueous solutions. It was supplied from the clay deposits of Horasan Formation of Pasinler Basin. This basin lies at approximately $50 \mathrm{~km}$ East of Erzurum, NE Turkey.

\section{Adsorbent characterization}

The chemical and mineralogical compositions of ECS were determined by X-ray powder diffraction (XRD) using Philips PW 1010/80 diffractometer with graphite-filtered $\mathrm{CuK} \alpha$ radiation. Furthermore, the $\mathrm{pH}$ values were determined with a $\mathrm{pH}$ meter (Thermo scientific Orion 5 star plus multifunction). The scanning electron microscope (SEM) was used to examine the surface of the adsorbent. Images of native adsorbent and metal loaded adsorbent were magnified 5000 times by SEM modeled JEOL JSM-6400 SEM. Before SEM examinations, the sample surfaces were coated with a thin layer $(20 \mathrm{~nm})$ of gold to obtain a conductive surface and to avoid electrostatic charging during examination. In addition, the Fourier Transform Infrared Spectroscopy (FTIR) analyses were carried out to identify functional groups and molecular structure in the adsorbent and copper loaded adsorbent. FTIR spectra were recorded using Perkin-a Perkin-Elmer GX 2000 FTIR spectrometer. The spectrum of the adsorbent was measured within the range of $4000-700 \mathrm{~cm}^{-1}$ wave number.

\section{Adsorbent preparation}

The ECS was thoroughly washed with distilled water until it became neutral. The suspension was wet sieved through a 200 mesh screen. A little amount of the suspension remained on the sieve and was discarded. The solid fraction was washed five times with distilled water following the sequence of mixing, settling, and decanting. The last suspension was filtered, and the residual solid was then dried at $105^{\circ} \mathrm{C}$, ground in a mortar, and sieved through a 200 mesh sieve. $1 \mathrm{~g}$ of this ECS sample was shaken with $10^{8} \mathrm{CFU} / \mathrm{mL} M$. extorquens solution for approximately $1 \mathrm{~h}$, and then the separated particles were stored. The ECS and bacteria-modified ECS were used in the study.

\section{Adsorption of copper ion on the natural and modified ECS}

For studying metal adsorption, $1 \mathrm{~g}$ of ECS as adsorbent was taken and it was then suspended in $50 \mathrm{~mL} \mathrm{CuCl}_{2}$ at $1 \mathrm{mg} / \mathrm{mL}$ concentration, at $\mathrm{pH}$ between 2.0 and 9.0 and contacted batchwise in a thermostatic $\left(\mathrm{t}=25^{\circ} \mathrm{C} \pm 0.1^{\circ} \mathrm{C}\right)$ water-bath agitator for $1 \mathrm{~h}$ to enable equilibration of the sorbent and solution 
phases. At each $\mathrm{pH}$, it was waited on for a term of $1 \mathrm{~h}$. Also, the same experiment was performed at varying temperatures in the $20-80$ range. The suspensions of samples were centrifuged at $5000 \mathrm{rpm}$ for $10 \mathrm{~min}$, and the supernatant was filtered through a $0.45 \mu \mathrm{m}$ pore, cellulosic membrane filter to make possible the measurement of the heavy metal concentration in the filtrate. After centrifuging, the amount of decreasing copper at the top level of liquid solution was measured. The copper ion concentration was determined by spectrophotometric method using 1-amino-2-hydroxy-4-naphthalenesulfonic acid (Seifullina and Skorokhod 1991). The amount of copper ions adsorbed was calculated as:

$$
q_{e}=\left(C_{o}+C_{e}\right) V / m
$$

where $q_{\mathrm{e}}(\mathrm{mg} / \mathrm{g})$ is the amount of adsorbed copper ions, $C_{o}$ $(\mathrm{mg} / \mathrm{L})$ is the initial concentration of copper, $C_{e}(\mathrm{mg} / \mathrm{L})$ is the concentrations of copper at equilibrium, $V(\mathrm{~L})$ is the volume of solution, and $m(\mathrm{~g})$ is the weight of ECS adsorbent. The same procedure was done by using bacteria-modified ECS.

\section{Results and discussion}

\section{Adsorbent properties}

The X-ray diffraction (XRD) pattern of the ECS is shown in Fig. 1. The XRD results show that the dominant clay mineral is smectite and the other non-clay minerals are quartz, calsite and feldispare. Its chemical composition consists of $\mathrm{Al}_{2} \mathrm{O}_{3}, \mathrm{Fe}_{2} \mathrm{O}_{3}$, $\mathrm{CaCO}_{3}, \mathrm{CaO}, \mathrm{MgO}, \mathrm{SiO}_{2}$ and $\mathrm{SO}_{3}$ (Table 1). The engineering properties of ECS have been determined by laboratory experiments and the results have been summarized in Table 1. It is over-consolidated and it has clayey-rock characteristics in natural conditions. It is defined as a high plasticity soil according to the Unified Soil Classification System. The ECS includes some fossils such as Dreissensia sp., Gastropoda sp. and Congeria sp (Kalkan and Bayraktutan 2008).

\section{Effect of contact time}

The effect of contact time on the adsorption process is illustrated in Fig. 2. It can be observed that the removal of copper increases with time in the first 180 and $30 \mathrm{~min}$ for natural and bacteria-modified ECS, respectively. It was

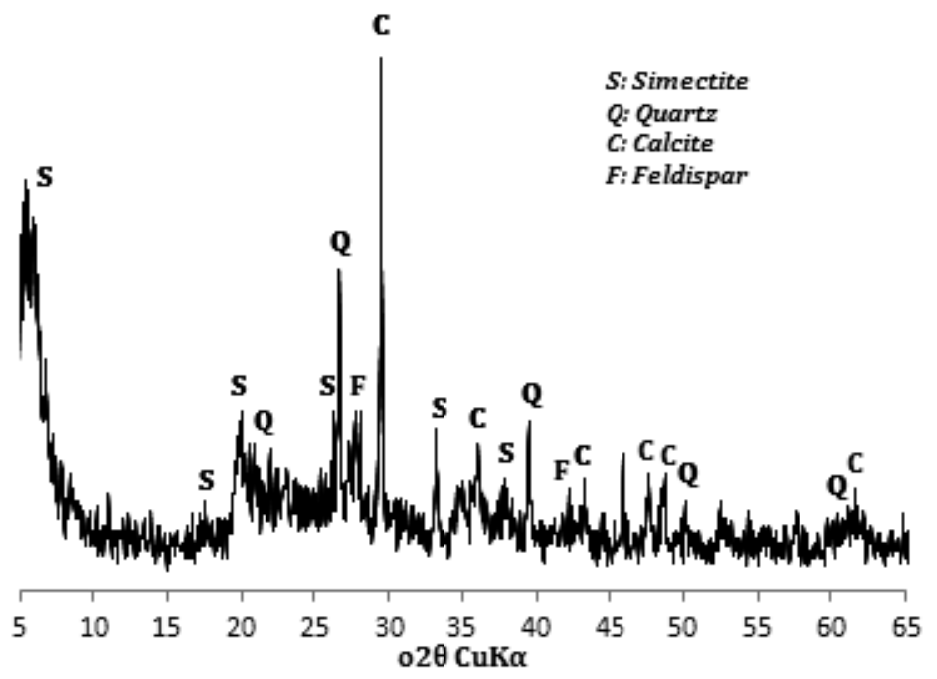

Fig. 1. XRD pattern for ECS sample used in this study

Table 1. Chemical and Engineering compositions and properties of ECS used in the study

\begin{tabular}{|c|c|c|c|}
\hline $\begin{array}{l}\text { Property } \\
\text { Compound }\end{array}$ & ECS & Density & ESC \\
\hline $\mathrm{Al}_{2} \mathrm{O}_{3}, \%$ & 10.32 & Density, $\left(\mathrm{mg} / \mathrm{m}^{3}\right)$ & 2.57 \\
\hline $\mathrm{Fe}_{2} \mathrm{O}_{3}, \%$ & 6.89 & \multicolumn{2}{|l|}{ Grain size } \\
\hline $\mathrm{CaO}_{3}, \%$ & 2.75 & Sand (2000-75 mm), \% & 26.5 \\
\hline $\mathrm{CaO}, \%$ & 13.65 & Silt $(2-75 \mathrm{~mm}), \%$ & 8.2 \\
\hline $\mathrm{MgO}, \%$ & 2.54 & Clay $(<2 \mathrm{~mm}), \%$ & 65.3 \\
\hline $\mathrm{SiO}_{2}, \%$ & 48.71 & \multicolumn{2}{|l|}{ Atterberg limits } \\
\hline $\mathrm{SO}_{3}, \%$ & 0.07 & Liquid limit, \% & 84.4 \\
\hline \multirow[t]{6}{*}{ Heat loss, \% } & 15.5 & Plastic limit, \% & 35.5 \\
\hline & & Plasticity index, \% & 48.9 \\
\hline & \multicolumn{3}{|c|}{ Adsorption } \\
\hline & & Water absorption, $\mathrm{ml} / 100 \mathrm{~g}$ & 34.28 \\
\hline & & Specific surface area & \\
\hline & & Specific surface area, $\mathrm{m}^{2} / \mathrm{g}$ & 36.2 \\
\hline
\end{tabular}


observed from Fig. 2 that the copper removal increases during the contact time. After that point there was no considerable change in copper removal recovery. This indicates that clay modification by bacteria provides rapid removal of copper ions. It is clearly shown that the amount of copper removal is higher in the beginning. This is probably due to a larger surface area of the ECS being available in the beginning for the adsorption of copper ions. As the surface adsorption sites become exhausted, the uptake rate is controlled by the rate at which the adsorbate is transported from the exterior to the interior sites of the adsorbent particles (Kalkan and Bayraktutan 2008, Kumar et al. 2011). This result is important, as equilibrium time is one of the important parameters for selecting a wastewater treatment system, when the time consumed for wastewater disposal should be considered. The rapid removal of the adsorbate has significant practical importance as it will facilitate smaller reactor volumes ensuring efficiency and economy (Aksu 2001, Dhabab 2011).

\section{Effect of $\mathrm{pH}$}

The $\mathrm{pH}$ of the aqueous solution is an important operational parameter in the adsorption process because it affects the solubility of the metal ions, concentration of the counter ions on the functional groups of the adsorbent and the degree of ionization of the adsorbate during reaction (Amuda et al. 2007). In other words, the uptake and percentage removal of metals from the aqueous solution are strongly affected by the $\mathrm{pH}$ of the solution (Ghazy and Ragab 2007, Onundi et al. 2010). In order to establish the effect of $\mathrm{pH}$ on the adsorption of copper ions, the batch equilibrium studies at different $\mathrm{pH}$ values in the range of 3-6 have been carried out. The effect of initial $\mathrm{pH}$ on the adsorption process is presented in Fig. 3. It is shown that the absorption amount of copper increases with increasing $\mathrm{pH}$ and maximum adsorption of copper ions are obtained at $\mathrm{pH} 5$ which is the initial $\mathrm{pH}$ of the solution for natural and bacteria-modified ECS. This is due to the surface complexation reactions, which are mostly influenced by the

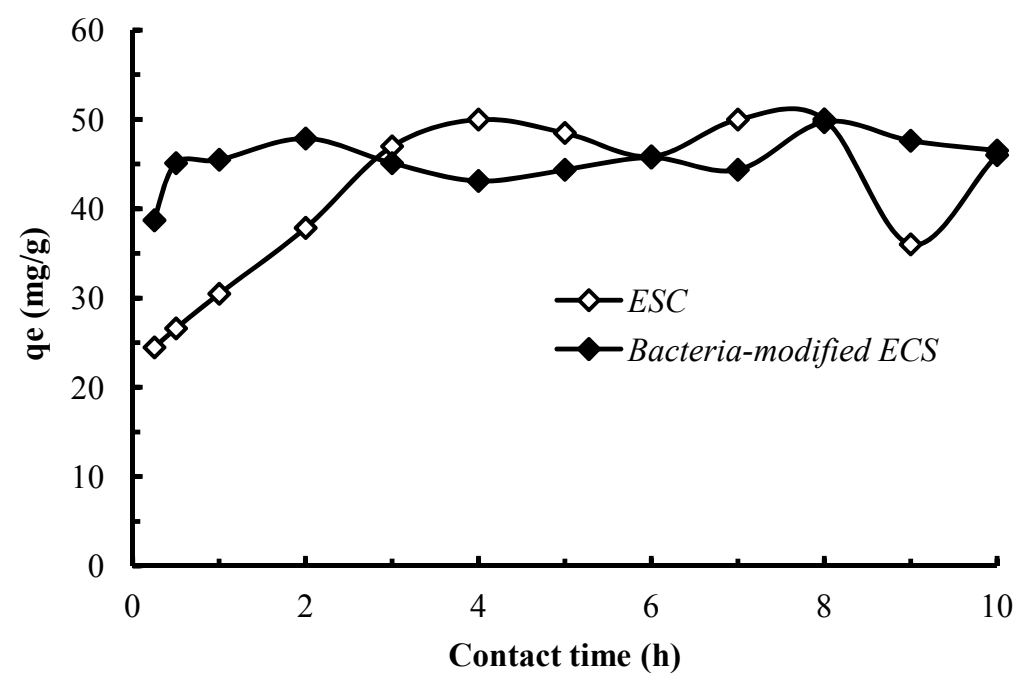

Fig. 2. Removal of copper as a function of equilibrium time $(\mathrm{pH}: 5.5$, initial copper concentration: $1 \mathrm{mg} / \mathrm{mL}$, adsorbent dose: $1 \mathrm{~g} / 50 \mathrm{~mL}$, agitation speed: $500 \mathrm{rpm}$ and temperature: $30 \pm 1^{\circ} \mathrm{C}$ )

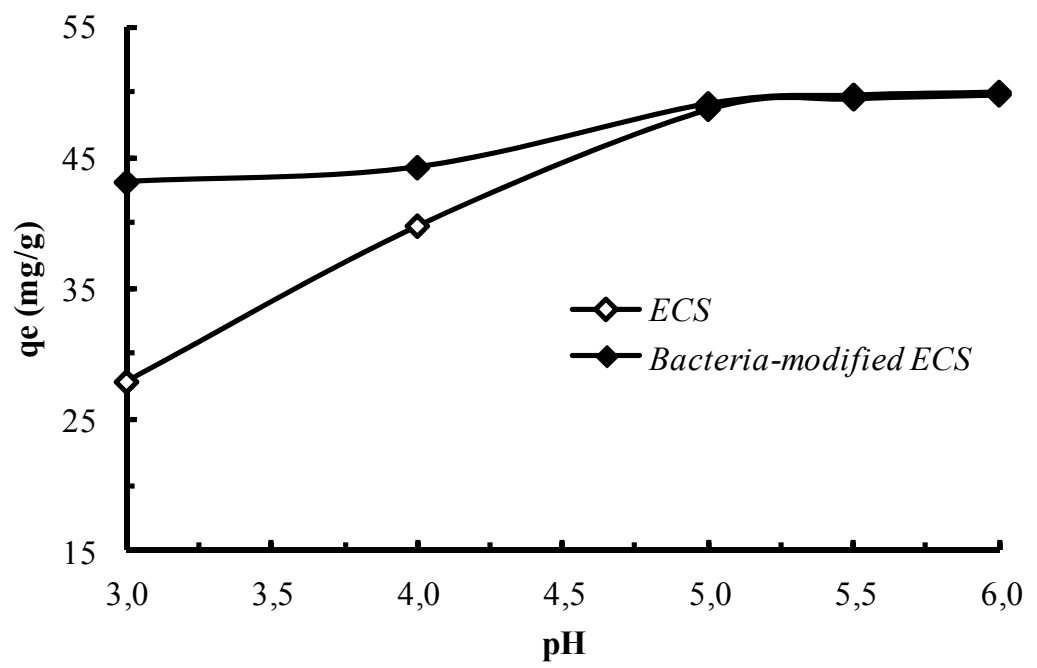

Fig. 3. Effect of copper as a function of $\mathrm{pH}$ (initial copper concentration: $1 \mathrm{mg} / \mathrm{mL}$, adsorbent dose: $1 \mathrm{~g} / 50 \mathrm{~mL}$, agitation speed: $500 \mathrm{rpm}$ and temperature: $30 \pm 1^{\circ} \mathrm{C}$ ) 
electrostatic force of attraction between copper and the surface of the adsorbent. The acidity of the medium can affect the metal ions uptake amount of the natural and bacteria-modified ECS adsorbent because hydrogen ions in the solution could compete with copper on the adsorbents surface (Rashad et al. 2011).

The removal of metal ions from aqueous solution by adsorption is highly dependent on the $\mathrm{pH}$ of the solution since this affects the surface charge of the adsorbent and the degree of ionization and speciation of the adsorbate (Bansal et al. 2009, Najua et al. 2008). From the results it was shown that the $\mathrm{pH}$ of the solution played a very important role in the metal uptake. The adsorbent surface metal binding sites as well as metal chemistry in solution were influenced by solution $\mathrm{pH}$. It is to be expected that with increase in $\mathrm{pH}$ values, more and more ligands having negative charge would be exposed which results in the increase in attraction of positively charged metal ions (Sekher et al. 1998). In low $\mathrm{pH}$ value, binding sites are generally protonated or positively charged (by the hydronium ions). Thus, repulsion occurs between the metal cation and the adsorbent at a higher $\mathrm{pH}$ value, binding sites start deprotonating and make different function groups available for metal binding. In general, cation binding increases as $\mathrm{pH}$ increases ( Dhabab 2011, Yang et al. 2016). Burkholderia sp. Z-90 has the ability to adsorb maximum $\mathrm{Cu}$ at $\mathrm{pH} 5$ which is similar to our results and similar to the results of Quan et al., and adsorption occurs at $\mathrm{pH}$ ranges from $3-6$. This $\mathrm{pH}$ range is widely accepted as being optimal for metal uptake of almost all types of adsorbent (Quan et al. 2013, Elouear et al. 2008).

\section{Effect of temperature}

Temperature is known to have a profound effect on various chemical processes. Temperature affects the adsorption rate by altering the molecular interactions and the solubility of the adsorbate (Quan et al. 2013). The effect of temperature influencing the adsorption has been studied in the range of $20-80^{\circ} \mathrm{C}$. The effect of temperature on the adsorption capacity of natural and bacteria-modified ECS is shown in Fig. 4. It is observed that the degree of adsorption increases with increasing temperature and the maximum adsorption of copper ions is obtained at 40 and $30^{\circ} \mathrm{C}$, which is the temperature of the solution for the natural and bacteria-modified ECS. The results in Fig. 4 show that the temperature did not have a significant effect on the $\mathrm{Cu}$ (II) biosorptions. Therefore, the process responsible for biosorption in this case seems to be largely physico-chemical in nature (Wang et al. 2005).

\section{Effect of initial metal ion concentration}

The variation in the amount of metal ion bound to the natural and bacteria-modified ECS with increasing initial metal ion concentration is illustrated in Fig. 5. The plot showing the effect of initial concentration on the adsorption of copper ions indicates that the total copper ions adsorbed by ECS slightly increased up to the end of the run and the total copper ions adsorbed by bacteria-modified ECS increased sharply in the beginning and then slowly towards the end of the run. When the initial copper ion concentration was increased from 1 to 10 , the amount of removed metal ions increased from 41.5 to $150.64 \mathrm{mg} / \mathrm{g}$ for the native ECS. Also, when copper ion concentration was increased from 1 to 7 , the amount of removed metal ions increased from 61.5 to $226.5 \mathrm{mg} / \mathrm{g}$ for the bacteria-modified ECS. This indicates that bacteria-modified ECS increases the amount of copper removal from aqueous solutions. The initial faster rate of removal of the metal ion could be due to the availability of the uncovered surface area of the adsorbents, since adsorption kinetics depends on the surface area of the adsorbent (Qadeer and Akhtar 2005). This trend is that of the result of the progressive increase in the electrostatic interaction between the copper ions and the adsorbent active regions. Moreover, this can be explained by the fact that more adsorption sites were being covered as the copper ions concentration increased (Kumar et al. 2011, Gupta et al. 2003). These could also be explained in terms of the progressive increase in the electrostatic interaction between the metal ion and the absorbent active regions, moreover, more adsorption sites were being covered as the metal ions concentration increased (Laraous et al. 2005). Besides, higher initial concentrations led to an increase in the affinity of the metal ion towards the active sites (Al-Asheh and Banat 2001).

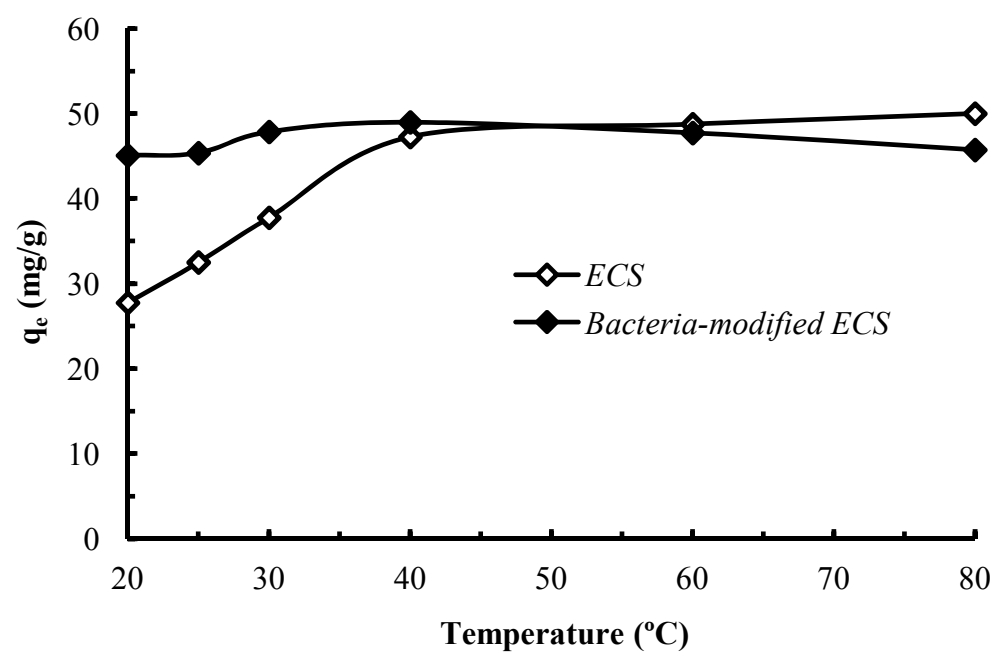

Fig. 4. Effect of temperature on the copper removal ( $\mathrm{pH}: 5.0$, initial copper concentration: $1 \mathrm{mg} / \mathrm{mL}$, adsorbent dose: $1 \mathrm{~g} / 50 \mathrm{~mL}$, agitation speed: $500 \mathrm{rpm}$, contact time $90 \mathrm{~min}$ ) 


\section{Effect of adsorbent dosage}

The dosage study is an important parameter in the adsorption studies because it determines the capacity of an adsorbent or a given initial concentration of metal in solution. A graph was plotted between the different dosages of adsorbent natural and bacteria-modified ECS, and the amount of copper removal. The effect of adsorbent dosages was studied by varying the sorbent amounts from 0.5 to $3 \mathrm{mg} / \mathrm{mL}$ (Fig. 6). The amount of metal ions removal increases from 14.2 to 43.6 and from 25.2 to $45.2 \mathrm{mg} / \mathrm{g}$ as the adsorbent dosage increases from 0.5 to 1 , and from 0.5 to $1 \mathrm{mg} / \mathrm{mL}$ for the natural and bacteria-modified ECS, respectively. It is seen that more copper ions are removed by bacteria-modified ECS for the same dosage. This indicates that adsorption increased with increasing natural and bacteria-modified ECS up to a certain value and then became almost constant. The results showed that the removal of copper ions increased rapidly with increase in the amount of natural and bacteria-modified ECS due to greater availability of the surface area at higher concentration of the adsorbent (Kumar et al. 2011, Nadaroglu and Kalkan 2014). This is because an increase in biomass concentration generally results in an increase in the surface area of the biosorbent with bacteria immobilized. The increase in adsorption with increase in adsorbent dosage is attributed to the availability of larger surface area and more adsorption sites. At a very low adsorbent concentration, the adsorbent surface becomes highly saturated with the metal ions and the residual metal ion concentration in the solution. It is plausible to suggest that with higher dosage of adsorbent there would be greater availability of exchangeable sites for metal ions as noted by Najua et al. (Najua et al. 2008). Moreover, the high adsorbent dosage could impose a screening effect on the dense outer layer of the cells, thereby shielding the binding sites from metals (Pons and Fuste 1993).

The copper concentration in the aqueous solution taken from samples of polluted river water solution treated with ECS and bacteria-modified ECS indicates that these

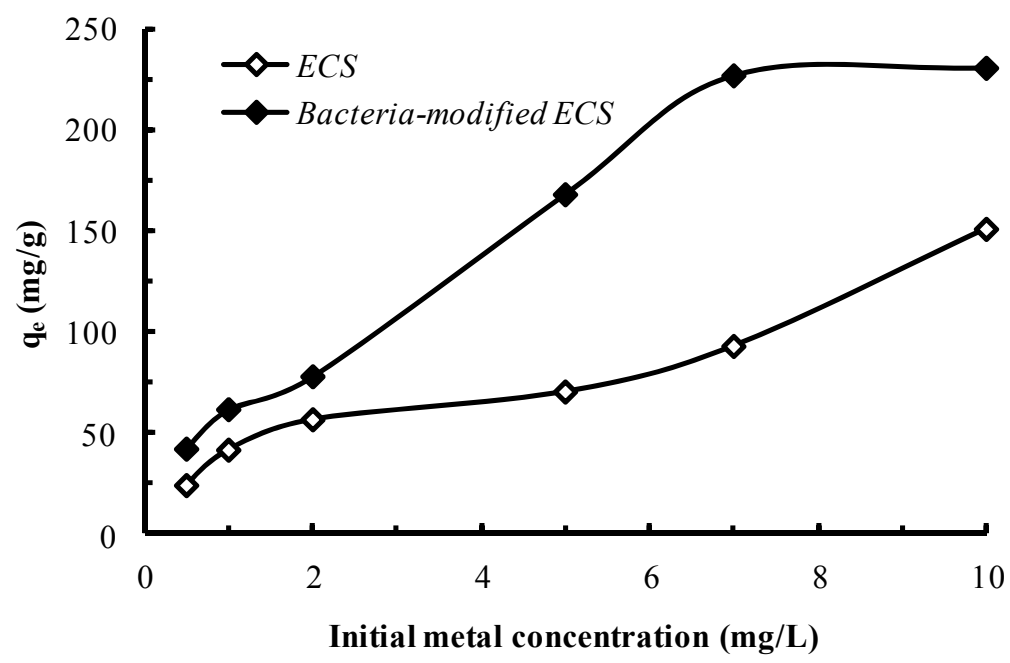

Fig. 5. Effect of initial metal ion concentration on the copper removal: $1 \mathrm{mg} / \mathrm{mL}$, adsorbent dose: $1 \mathrm{~g} / 50 \mathrm{~mL}$, agitation speed: $500 \mathrm{rpm}$ and temperature: $30 \pm 1^{\circ} \mathrm{C}$ )

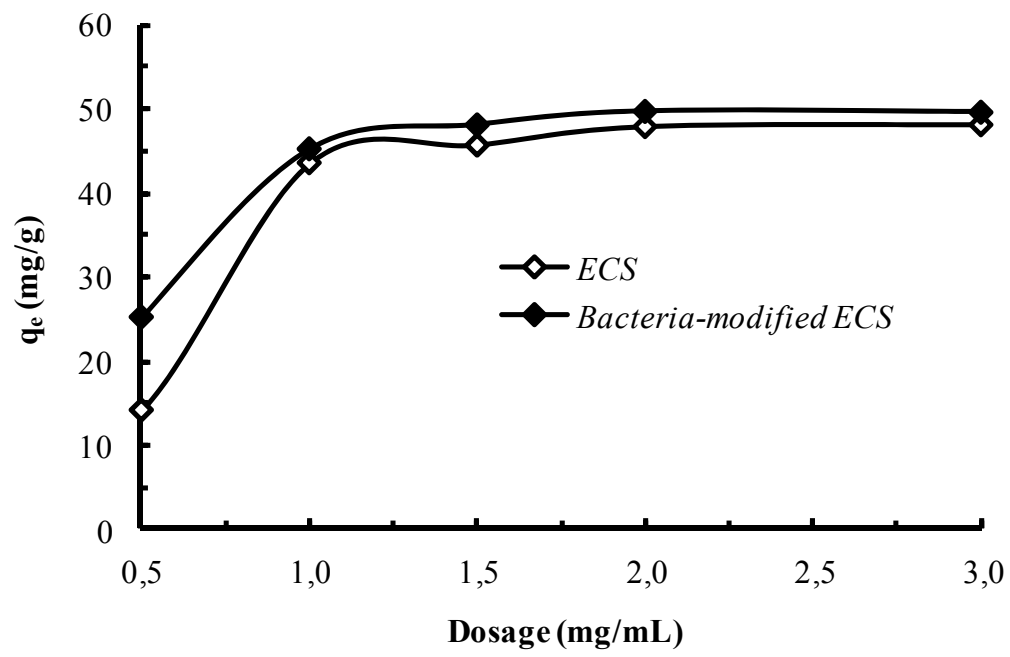

Fig. 6. Effect of adsorbent dosage on the copper removal $(\mathrm{pH}: 5.0$, initial copper concentration: $1 \mathrm{mg} / \mathrm{mL}$, agitation speed: $500 \mathrm{rpm}$, contact time $60 \mathrm{~min}$ ) 
absorbents enhanced adsorption capacity. Without the addition of the adsorbents, the leachate copper concentration had approximately 1.262 and $11.742 \mathrm{mg} / \mathrm{mL}$ for polluted river water and $\mathrm{CuCl}_{2}$ solutions, respectively. The addition of ECS and bacteria-modified ECS strongly inhibited the leaching of copper in both solutions. When the ECS and bacteria-modified ECS are added to the aqueous solutions contaminated with copper, the concentration of copper in the leachate drastically decreases, whereas the adsorption capacity increases. It is seen from Fig. 7 that the copper concentration in the samples of ECS and bacteria-modified ECS treated leachates solution of polluted river water decreases from 1.262 to 0.456 and from 1.262 to 0.120 , respectively. Similarly, the copper concentration in the samples of ECS and bacteria-modified ECS treated leachates solution of $\mathrm{CuCl}_{2}$ solution decreases from 11.742 to 4.115 and from 11.742 to 0.860 , respectively. It is seen that the bacteria-modified ECS adsorbent has a high level of adsorption capacity for copper ions more than the ECS (Fig. 7).

\section{SEM study on adsorbed surface}

The SEM enables the direct observation of the surface microstructures of different adsorbents (Onundi et al. 2010). Images of native adsorbent (Fig. 8A) and metal loaded adsorbent (Fig. 8B and 8C) were magnified 1000 times. SEM was used to examine the surface of the adsorbents. It was observed that there are some cavities on the ESC and bacteria-modified ESC surface, which become larger in size for large size of ESC and bacteria-modified ESC. The above observations showed that the cavities on the ESC and bacteria-modified ESC surface were the active centers, and these centers were attracted to the copper ions for adsorption. Thus the amount of adsorbed equilibrium increased as the particle surface size of ESC and bacteria-modified ESC got larger.

\section{Equilibrium adsorption studies}

Equilibrium data, commonly known as adsorption isotherms, are basic requirements for the design of an adsorption system. In an adsorption isotherm study, several equilibrium models have been developed to describe adsorption isotherm relationships.
The Langmuir (Langmuir 1918) and Freundlich (Freundlich 1926) equations are the world-widely used models because of their simplicity (Polowczyk et al. 2007). Langmuir adsorption isotherm is often used to describe the maximum adsorption capacity of an adsorbent and it is given as:

$$
q_{e}=q_{m} K_{L} C_{e} /\left(1+K_{L} C_{e}\right)
$$

where $q_{\mathrm{e}}(\mathrm{mg} / \mathrm{g})$ is the adsorption amount of adsorbent at equilibrium, $q_{\mathrm{m}}(\mathrm{mg} / \mathrm{g})$ is the maximum adsorption amount of metal ions, $C_{e}(\mathrm{mg} / \mathrm{L})$ is the equilibrium concentration of adsorbate in solution and $K_{L}(\mathrm{~L} / \mathrm{mg})$ is the equilibrium adsorption constant which is related to the affinity of the binding sites. The Langmuir constants $K_{L}$ and $q_{m}$ are calculated with the following equation:

$$
C_{e} / q_{e}=\left(1 / K_{L} q_{m}\right)+\left(C_{e} / q_{m}\right)
$$

where $C_{e}(\mathrm{mg} / \mathrm{L})$ is the equilibrium concentration of adsorbate in solution, $q_{e}(\mathrm{mg} / \mathrm{g})$ is the adsorption amount of adsorbent at equilibrium, $q_{m}(\mathrm{mg} / \mathrm{g})$ is the maximum adsorption amount of metal ions and $K_{L}(\mathrm{~L} / \mathrm{mg})$ is the equilibrium adsorption constant which is related to the affinity of the binding sites. The Freundlich isotherm is based on the assumption that adsorption is on a heterogeneous surface and exponential distribution of sites and their energies (Polowczyk et al. 2007), which can be expressed by the following equation:

$$
q_{m}=K_{F} C_{e}^{1 / n}
$$

where $q_{m}(\mathrm{mg} / \mathrm{g})$ is the maximum adsorption amount of metal ions, $C_{e}(\mathrm{mg} / \mathrm{L})$ is the equilibrium concentration of adsorbate in solution. $K_{F}(\mathrm{mg} / \mathrm{g})$ and $\mathrm{n}$ are the Freundlich constants related to the sorption capacity of the adsorbent and the energy of adsorption, respectively. They can be calculated in the following linear form:

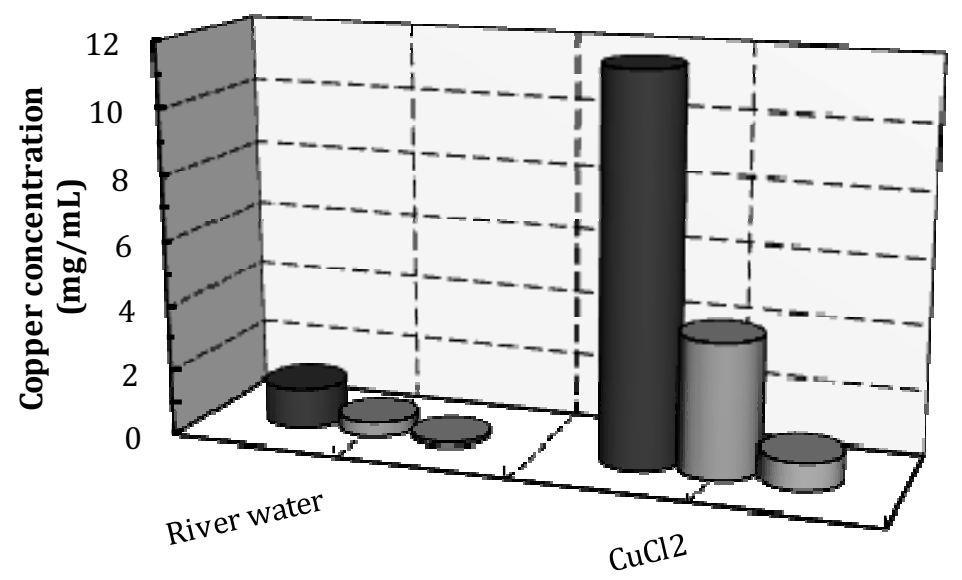

Aqueous solutions

Untreated

- Treated by ECS

$\square$ Treated by bacteria-modified ECS

Fig. 7. Variation of copper concentration with natural and bacteria-modified ECS on the river water and $\mathrm{CuCl}_{2}$ 

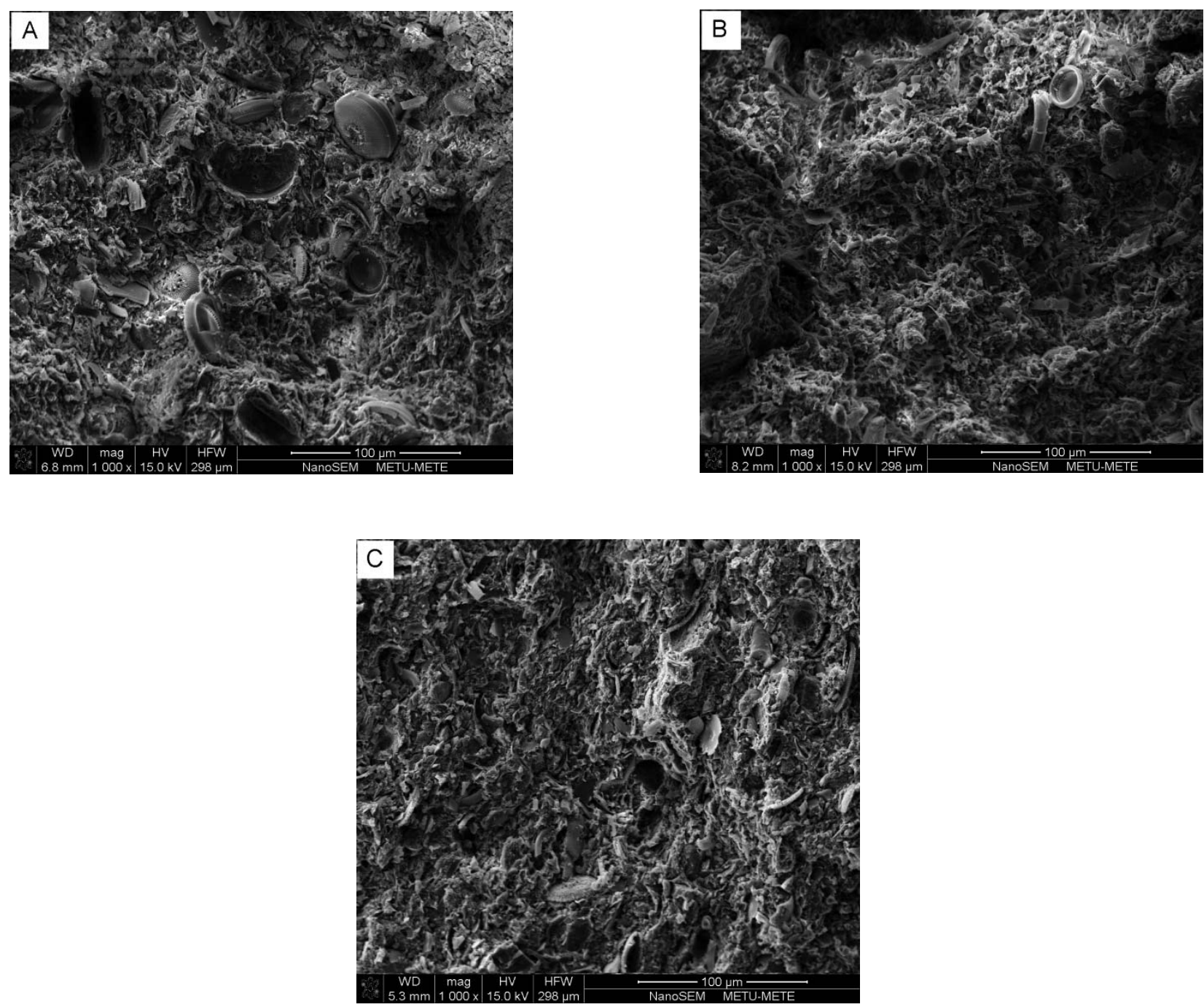

Fig. 8. SEM analysis of copper adsorbed ESC surface A: Before adsorption with copper; B: After adsorption with copper by using ESC; C: After adsorption with copper by using bacteria-modified ESC (pH: 5 , temperature: $\left.30 \pm 1^{\circ} \mathrm{C}\right)$

$$
\log q_{e}=\log K_{F}+1 / n \log C_{e}
$$

where $q_{e}(\mathrm{mg} / \mathrm{g})$ is the adsorption amount of adsorbent at equilibrium, $C_{e}(\mathrm{mg} / \mathrm{L})$ is the equilibrium concentration of adsorbate in solution, $K_{F}(\mathrm{mg} / \mathrm{g})$ and $\mathrm{n}$ are the Freundlich constants related to the sorption capacity of the adsorbent and the energy of adsorption.

The Langmuir and Freundlich isotherms were obtained from the experiments. The graphical comparison of the experimental value with the calculated value from the Freundlich and Langmuir isotherms for copper adsorption by natural and bacteria-modified clay are shown in Figs 9 and 10. It is obvious that the adsorption capacities calculated from the Langmuir isotherms are much closer to the experimental values of adsorption capacity than that of Freundlich isotherms. The constants of Freundlich and Langmuir isotherms and correlation coefficients calculated from the adsorption data are given in Table 2. The high correlation coefficients show that both models are suitable for describing the adsorption equilibrium of copper ions. The adsorption capacity of natural and bacteria-modified ECS adsorbent for the uptakes of copper is 79.37 and $93.46 \mathrm{mg} / \mathrm{g}$, respectively (Gangoli et al. 1975, Ramesh et al. 2005, Demirbas et al. 2008, Nadaroglu et al. 2015).

\section{Thermodynamics studies}

The sorption capacity of natural and bacteria-modified clay adsorbent increased together with increase in the temperature of the system from 293-313 K. Thermodynamic parameters such as change in free energy $\left(\Delta \mathrm{G}^{\circ}\right) \mathrm{kJ} / \mathrm{mol}$, enthalpy $\left(\Delta \mathrm{H}^{\circ}\right)$ $\mathrm{kJ} / \mathrm{mol}$, and entropy $\left(\Delta \mathrm{S}^{\circ}\right) \mathrm{J} / \mathrm{Kmol}$ were determined using the following equations:

$$
\begin{gathered}
K D=C s / C e \\
D G^{\circ}=-R T \ln K L \\
\ln K L=\left(D S^{\circ} / R\right)-\left(D H^{\circ} / R T\right)
\end{gathered}
$$

where $K_{L}$ is the equilibrium constant, $C s$ is the solid phase concentration at equilibrium $(\mathrm{mg} / \mathrm{L}), \mathrm{Ce}$ is the liquid phase concentration at equilibrium $(\mathrm{mg} / \mathrm{L}), \mathrm{T}$ is the temperature in Kelvin, and $\mathrm{R}$ is the gas constant.

From the temperature variation from 293 to $313 \mathrm{~K}$ on the sorption, $\Delta \mathrm{H}^{\circ}$ and $\Delta \mathrm{S}^{\circ}$ were obtained (Fig. 11). The $\Delta \mathrm{H}_{\text {ads }}^{\circ}$ and $\Delta \mathrm{S}_{\text {ads }}^{\circ}$ values obtained from the slope and intercept of Van't Hoff plots are presented in Table 3. Gibbs free energy $(\Delta G)$ was calculated as: 


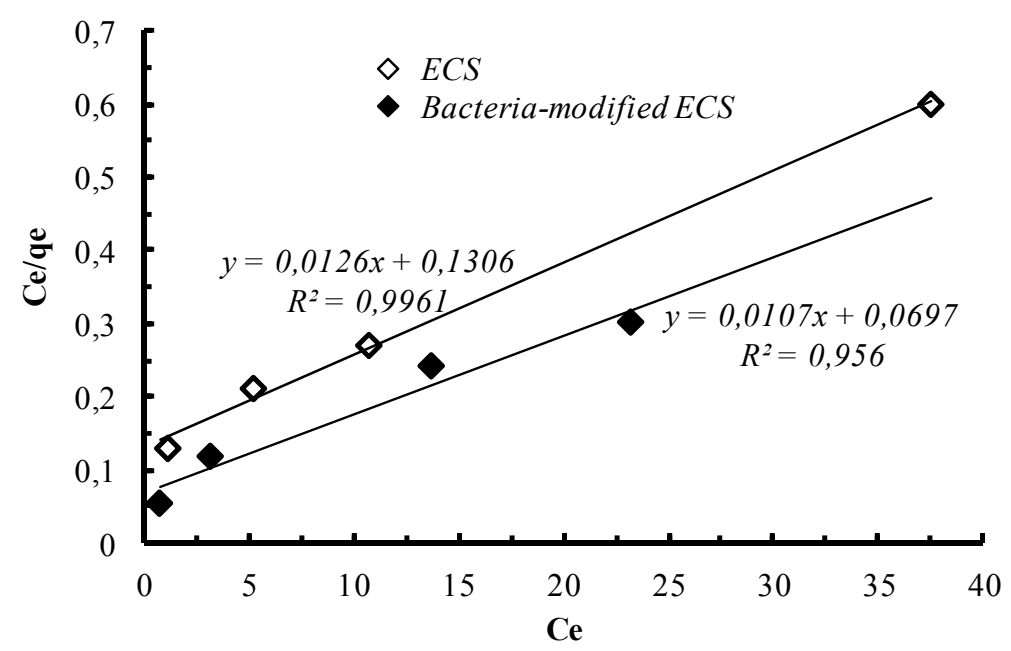

Fig. 9. The Langmuir isotherm for the adsorption of copper by natural and bacteria-modified ECS

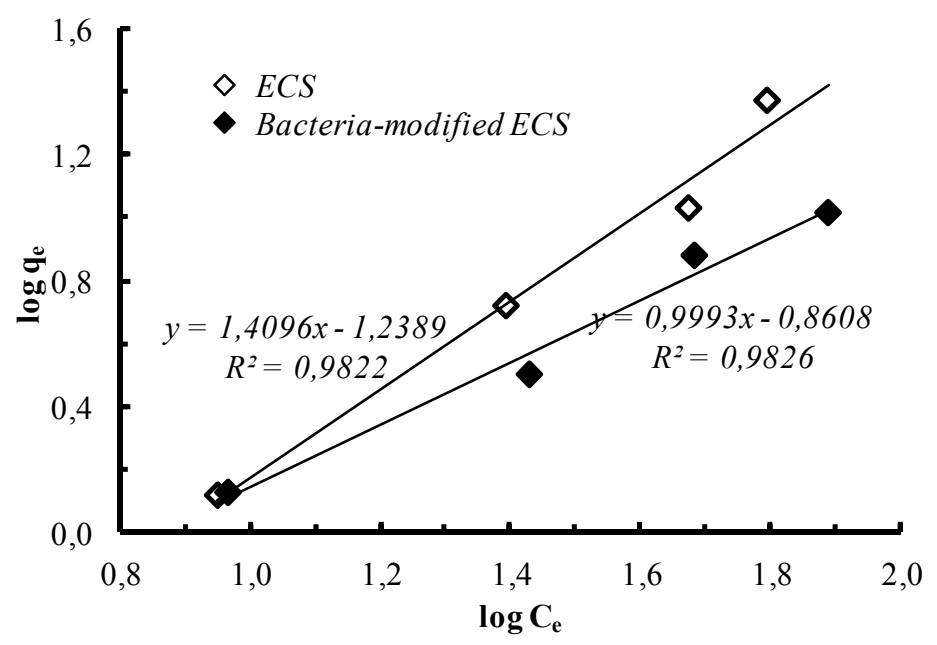

Fig. 10. The Freundlich isotherm for the adsorption of copper by natural and bacteria-modified ECS

Table 2. Values of adsorption isotherm parameters for adsorption of copper

\begin{tabular}{|lcc|}
\hline & ECS & Bacteria-modified ECS \\
\hline Langmuir constant & & \\
$Q_{M}(\mathrm{mg} / \mathrm{g})$ & 79.37 & 93.46 \\
$K_{L}(\mathrm{~L} / \mathrm{mg})$ & 0.1306 & 0.00075 \\
$R^{2}$ & 0.9961 & 0.9560 \\
\hline Freundlich constant & & \\
$K F$ & 0.058 & 0.138 \\
$n$ & 0.709 & 1.000 \\
$R^{2}$ & 0.9822 & 0.9826 \\
\hline
\end{tabular}

$$
\Delta G^{\circ}=\Delta H^{\circ}-T \Delta S-T D S
$$

The values of the thermodynamic parameters for the sorption of $\mathrm{Cu}$ (II) on clay soil and modified clay soil adsorbents are given in Table 3.

The Gibbs free energy change $\left(\mathrm{DG}^{\circ}\right)$ was calculated to be $-0.68,-2.20,-3.72$ and $-6.76 \mathrm{kJmol}^{-1}$ on ESC and -5.10 ,
$-6.36,-7.62$ and $-10.14 \mathrm{kJmol}^{-1}$ on bacteria-modified ESC for $\mathrm{Cu}^{2+}$ adsorption at 293, 298, 303, $313 \mathrm{~K}$, respectively. Negative $\mathrm{DG}^{\circ}$ values which were obtained for $\mathrm{Cu}^{2+}$ at each of the temperatures studied indicated the feasibility of the process and spontaneous nature of the adsorption. The $\mathrm{DG}^{\circ}$ values decreased with an increase in temperature, indicating an increased trend in the degree of spontaneity and feasibility 


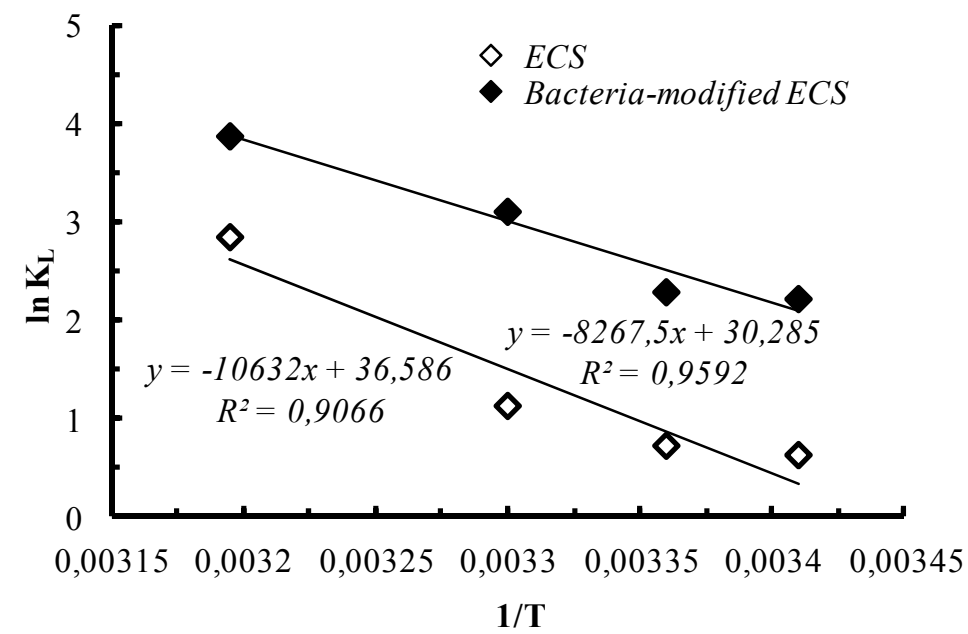

Fig. 11. Influence of temperature on the thermodynamic behavior of adsorption of copper onto natural and bacteria-modified ECS adsorbent

Table 3. Thermodynamic parameters for the adsorption of copper onto ECS and modified ECS adsorbents

\begin{tabular}{|l|c|c|c|c|c|c|}
\hline & $\Delta \mathrm{H}_{\mathrm{ads}}{ }^{\circ}\left(\mathrm{kJmol}^{-1}\right)$ & $\Delta \mathrm{S}_{\mathrm{ads}}{ }^{\circ}\left(\mathrm{kJmol}^{-1}\right)$ & \multicolumn{4}{|c|}{$\Delta \mathrm{G}_{\mathrm{ads}}{ }^{\circ}\left(\mathrm{kJmol}^{-1}\right)$} \\
\hline & & & $293 \mathrm{~K}$ & $298 \mathrm{~K}$ & $303 \mathrm{~K}$ & $313 \mathrm{~K}$ \\
\hline ECS & 88.39 & 30.42 & -88.25 & -89.77 & -91.29 & 94.33 \\
\hline Bacteria-modified ECS & 68.74 & 25.18 & -73.09 & 74.35 & 75.61 & 78.13 \\
\hline
\end{tabular}

of $\mathrm{Cu}^{2+}$ adsorption. The $\mathrm{DH}^{\circ}$ parameter was found to be $88.39,68.74 \mathrm{~kJ} / \mathrm{mol}$ for $\mathrm{Cu}^{2+}$ adsorption, on ESC and bacteria-modified ESC, respectively. The positive values of $\mathrm{DH}^{\circ}$ further confirmed the endothermic nature of the adsorption process. The heat of adsorption value between 20 and $400 \mathrm{~kJ} / \mathrm{mol}$ indicates the chemisorption process (Unlu and Ersoz 2007). Hence, the adsorption of $\mathrm{Cu}^{2+}$ on clay soil and modified clay soil was chemical in nature. The $\mathrm{DS}^{\circ}$ parameter was found to be 304.2 and $251.8(\mathrm{~J} / \mathrm{mol} \mathrm{K})$ for $\mathrm{Cu}^{2+}$ adsorption on ESC and bacteria-modified ESC, respectively. The positive values of $\mathrm{DS}^{\circ}$ suggested that the degrees of freedom increased at the solid-liquid interface during the adsorption. During the adsorption process, the coordinated water molecules were displaced by metal cations, resulting in increased randomness in the adsorbent-adsorbate system (Baraka et al. 2007, Li et al. 2011).

\section{Conclusions}

In this study, firstly, ECS was converted into an adsorbent, and the suitability of the bacteria-modified ECS with M. extorquens for adsorption of copper from the wastewater and standard $\mathrm{CuCl}_{2}$ solutions was investigated. Secondly, optimal adsorption conditions were analyzed. It was observed that the maximum copper removal was at the $\mathrm{pH} 5.0$ for both ECS and the bacteria-modified ECS. The adsorption is too fast at the first $30 \mathrm{~min}$ of contact time for the bacteria-modified ECS. The rapid removal of the adsorbate has significant practical importance as it will facilitate smaller reactor volumes ensuring efficiency and economy. It is observed that the degree of adsorption increases with increasing temperature and maximum adsorption of copper ions are obtained at $30^{\circ} \mathrm{C}$ which is the temperature of the solution for the bacteria-modified ECS.

Thirdly, isoterm data of $\mathrm{Cu}^{2+}$ adsorption on ECS and M-ECS were calculated. Based on the correlation coefficient values, it has been deduced that the Langmuir and Freundlich isotherms are suitable for fitting the experimental findings. The high correlation coefficient showed that the Langmuir and Freundlich adsorption isotherm models are suitable for describing the adsorption equilibrium of copper ions. The adsorption of $\mathrm{Cu}$ (II) ions on to ESC and bacteria-modified ESC shows negative $\mathrm{DG}^{\circ}$ values which indicates that sorption process is physisorption. The investigation showed that the ECS and the bacteria-modified ECS are very valuable material for the removal of copper ions from aqueous solutions. In addition, the use of the bacteria-modified ECS for the removal of copper ions from the aqueous solutions can potentially reduce the remediation costs.

\section{References}

Ahmad, A., Rafatullah, M., Sulaiman, O., Ibrahim, M.H., Chii, Y.Y. \& Siddique, B.M. (2009). Removal of $\mathrm{Cu}$ (II) and $\mathrm{Pb}$ (II) ions from aqueous solutions by adsorption on sawdust of Meranti wood, Desalination, 247, pp. 636-646.

Aksu, Z. (2001). Equilibrium and kinetic modelling of cadmium (II) biosorption by C. vulgaris in a batch system: effect of temperature, Separation and Purification Technology, 21, pp. 285-294.

Aksu, Z. \& Isoglu, I.A. (2005). Equilibrium and kinetic modelling of cadmium (II) biosorption by $C$. vulgaris in a batch system: effect of temperature, Process Biochemistry, 40, pp. 3031-3044. 
Al-Asheh, S. \& Banat, F. (2001). Adsorption of Zn (II) and Cu (II) ions by the solid waste of the olive oil industry, Adsorption Science and Technology, 19, pp. 117-129.

Amuda, O.S., Giwa, A.A. \& Bello, I.A. (2007). Removal of heavy metal from industrial wastewater using modified activated coconut shell carbon, Biochemical Engineering Journal, 36, pp. 174-181.

Bansal, M., Singh, D., Garg, V.K. \& Rose, P. (2009). Use of agricultural waste for the removal of nickel ions from aqueous solutions: equilibrium and kinetics studies, World Academy of Science Engineering and Technology, 51, pp. 431-437.

Bansal, R.C. \& Goyal, M. (2005). Activated carbon adsorption, CRC Press Taylor \& Francis Group LCC, ISBN 0-8247-5344-5, Boca Raton, Florida, USA 2005.

Baraka, A., Hall, P.J. \& Heslop, M.J.(2007). Preparation and characterization of amine-formaldehyde-DTPA chelating resin and its use as an adsorbent for heavy metals removal from wastewater, Reactive and Functional Polymers, 67, pp. 585-600.

Benaissa, H. \& Elouchdi, M.A. (2007). Removal of copper ions from aqueous solutions by dried sunflower leaves, Chemical Engineering and Processing, 46, pp. 614-622.

Bhatnagara, A., Minocha, A.K. \& Sillanpaa, M. (2010). Adsorptive removal of cobalt from aqueous solution by utilizing lemon peel as biosorbent, Biochemical Engineering Journal, 48, pp. 181-186.

Bhattacharyya, K.G. \& Gupta, S.S. (2008). Adsorption of a few heavy metals on natural and modified kaolinite and montmorillonite: A review, Advances in Colloid and Interface Science, 140, pp. 114-131.

Chen, X., Chen, G., Chen, L., Chen, Y., Lehmann, J., McBride, M.B. \& Hay, A.G. (2011). Adsorption of copper and zinc by biochars produced from pyrolysis of hardwood and corn straw in aqueous solution, Bioresource Technology, 102, pp. 8877-8884.

Demirbas, D., Karadag, A., Aklan, M. \& Dogan, M. (2008). Removal of copper ions from aqueous solutions by hazelnut shell, Journal of Hazardous Materials, 153, pp. 677-684.

Dhabab, J.M. (2011). Removal of some heavy metal ions from their aqueous solutions by duckweed, Journal of Toxicology and Environmental Health Sciences, 3, 6, pp. 164-170.

Dias, J.M., Alvim-Ferraz, M.C.M., Almeida, M.F., Rivera-Utrilla, J. \& Sanchez-Polo, M. (2007). Waste materials for activated carbon preparation and its use in aqueous-phase treatment: a review, Journal of Environmental Management, 85, pp. 833-846.

Elouear, Z., Bouzid, J., Boujelben, N., Feki, M., Jamoussi, F. \& Montiel, A. (2008). Heavy metal removal from aqueous solutions by activated phosphate rock, Journal of Hazardous Materials, 156, pp. 412-420.

Freundlich, H. \& Hatfield, H. (1926). Colloid and Capillary Chemistry, Methuen and Co Ltd, London 1926.

Gangoli, N., Markey, D.C. \& Thodos, G. (1975). In Proceedings of the Second National Conference on Complete Water Reuse: Water's Interface with Energy Air and Solids, Chicago, IL, AIChE. 3, pp. 270-275.

Ghazy, S.E. \& Ragab, A.H. (2007). Removal of copper from water samples by sorption onto powdered limestone, Indian Journal of Chemical Technology, 14, pp. 507-514.

Gupta, V.K., Jain, C.K., Ali, I., Sharma, M. \& Saini, V.K. (2003). Removal of cadmium and nickel from wastewater using bagasse fly ash - a sugar industry waste, Water Research, 37, pp. 4038-4044.

Ibrahim, M.N.M., Ngah, W.S.W., Norliyana, M.S. \& Daud, W.R.W. (2009). Copper (II) biosorption on soda lignin from oil palm empty fruit bunches (EFB), Clean - Soil, Air, Water, 37, pp. $80-85$.

Jaman, H., Chakraborty, D. \& Saha, P. (2009). A study of the thermodynamics and kinetics of copper adsorption using chemically modified rice husk, Clean - Soil, Air, Water, 37, pp. 704-711.
Jan, S., Roblot, C., Courtois, J., Courtois, B., Barbotin, J.N. \& Seguin, J.P. (1996). H-NMR spectroscopic determinatin of poly 3-hydroxybutyrate extracted from microbial biomass, Enzyme and Microbial Technology, 18, pp. 195-201.

Kakitani, T., Hata, T., Kajimoto, T., Koyanaka, H. \& Imamura, Y. (2009). Characteristics of a bioxalate chelating extraction process for removal of chromium, copper and arsenic from treated wood, Journal of Environmental Management, 90, pp. 1918-1923.

Kalkan, E. \& Bayraktutan, M.S. (2008). Geotechnical evaluation of Turkish clay deposits: a case study in Northern Turkey, Environmental Geology, 55, pp. 937-950.

Kalkan, E., Nadaroglu, H. \& Demir, N. (2012). Experimental study on the nickel (II) removal from aqueous solutions using silica fume with/without apocarbonic anhydrase, Desalination and Water Treatment, 44, pp. 180-189.

Kalkan, E. \& Yarbaş1, N. (2013). Use of marble dust waste material for stabilization of compacted clayey soils, Jokull Journal, 63, 5, pp. 322-344.

Kumar, P.S., Ramalingam, S., Sathyaselvabala, V., Kirupha, S.D. \& Sivanesan, S. (2011). Removal of copper (II) ions from aqueous solution by adsorption using cashew nut shell, Desalination, 266, pp. 63-71.

Langmuir, I. (1918). The adsorption of gases on plane surfaces of glass, mica and platinum, Journal of the American Chemical Society, 40, 8, pp. 1361-1403.

Laraous, S., Meniai, A.H. \& Bencheikh Lehocine, M. (2005). Experimental study of the removal of copper from aqueous solutions by adsorption using sawdust, Desalination, 185, pp. 483-490.

Li, X., Yanfeng Li, Y. \& Ye, Z. (2011). Preparation of macroporous bead adsorbents based on poly(vinyl alcohol)/chitosan and their adsorption properties for heavy metals from aqueous solution, Chemical Engineering Journal, 178, pp. 60-68.

Nadaroglu, H. \& Kalkan, E. (2014). Removal of copper from aqueous solution using silica fume with/without apocarbonic anhydrase, Indian Journal of Chemical Technology, 21, pp. 249-256.

Nadaroglu, H. \& Kalkan, E. (2012). Alternative absorbent industrial red mud waste material for cobalt removal from aqueous solution, International Journal of Physical Sciences, 7, 9, pp. 1386-1394.

Nadaroglu, H., Kalkan, E. \& Celebi, N. (2014). Removal of copper from aqueous solutions by using Berriasiyen-Aptian aged micritic limestone, Carpathian Journal of Earth And Environmental Sciences, 9, 1, pp. 69-80.

Nadaroglu, H., Kalkan, E. \& Celik, H. (2015). Equilibrium studies of copper ion adsorption onto modified and powdered kernel of date (Fructus dactylus), International Journal of Environmental Science and Technology, 12, pp. 2079-2090.

Nadaroglu, H, Kalkan, E. \& Demir, N. (2010). Removal of copper from aqueous solution using red mud, Desalination, 153, pp. 90-95.

Najua, D.T., Luqman, C.A., Zawani, Z. \& Suraya, A.R. (2008). Adsorption of copper from aqueous solution by Elais Guineensis kernel activated carbon, Journal of Engineering Science and Technology, 3, pp. 180-189.

Nohut, S., Karabocek, S., Guner, S. \& Gok, Y. (1999). Extraction and spectrophotometric determination of copper (II) with S, S'-bis(2-aminophenyl)oxalate, Journal of Pharmaceutical and Biomedical Analysis, 20, pp. 309-314.

Onundi, Y.B., Mamun, A.A., Al Khatib, M.F. \& Ahmed, Y.M. (2010). Adsorption of copper, nickel and lead ions from synthetic semiconductor industrial wastewater by palm shell activated carbon, International Journal of Science and Technology, 7, pp. 751-758.

Polowczyk, I., Bastrzyk, A., Kozlecki, T., Rudnicki, P., Sawinski, W. \& Sadowski, Z. (2007). Application of fly ash agglomerates in the sorption of arsenic, Polish Journal of Chemical Technology, 9, pp. 37-41. 
Pons, M.P. \& Fuste, C.M. (1993). Uranium uptake by immobilized cells of Pseudomonas strain EPS 5028, Applied Microbiology and Biotechnology, 39, pp. 661-665.

Qadeer, R. \& Akhtar, S. (2005). Kinetics study of lead ion adsorption on active carbon, Turkish Journal of Chemistry, 29, pp. 95-99.

Quan, H., Bai, H., Han, Y., Kang, Y. \& Sun, J. (2013). Removal of Cu(II) and $\mathrm{Fe}$ (III) from aqueous solutions by dead sulfate reducing bacteria, Frontiers of Chemical Science and Engineering, 7, 2, pp. 177-184.

Ramesh, A., Lee, D.J. \& Wong, J.W.C. (2005). Thermodynamic parameters for adsorption equilibrium of heavy metals and dyes from wastewater with low-cost adsorbents, Journal of Colloid and Interface Science, 291, pp. 588-592.

Rashad, M.M., Hessien, M.M., Abdel-Aal, E.A., El-Barawy, K. \& Singh, R.K. (2011). Transformation of silica fume into chemical mechanical polishing (CMP) nano-slurries for advanced semiconductor manufacturing, Powder Technology, 205, pp. 149-154.

Sahan, T., Ceylan, H., Sahiner, N. \& Aktas, N. (2010). Optimization of removal conditions of copper ions from aqueous solutions by Trametes versicolor, Bioresource Technology, 101, pp. 4520-4526.

Sarioglu, M., Guler, U.A. \& Beyazit, N. (2009). Removal of copper from aqueous solutions by phosphate rock, Desalination, 239 , pp. 167-174.

Sarioglu, M., May, O.A. \& Cebeci, Y. (2005). Removal of copper from aqueous solutions by phosphate rock, Desalination, 181, pp. 303-311.
Seifullina, I.I. \& Skorokhod, L.S. (1991). Spectrophotometric study of the reaction of copper (II), nickel (II), and cobalt (II) salts with 1-amino-2-hydroxy-4-naphthalenesulfonic acid, Zhurnal Obshchei Khimii Russia Journal of General Chemistry, 61, pp. 2005-2008.

Sekher, K.C., Subramanian, S., Modak, J.M. \& Natarajan, K.A. (1998). Removal of metal ions using an industrial biomass with reference to environmental control, International Journal of Mineral Processing, 53, pp. 107-120.

Unlu, N. \& Ersoz, M. (2007). Removal of heavy metal ions by using dithiocarbamatedsporopollenin, Separation and Purification Technology, 52, pp. 461-469.

Wang, R., Men, J. \& Gao, B. (2012). The adsorption behavior of functional particles modified by polyvinylimidazole for $\mathrm{Cu}$ (II) ion, Clean-Soil, Air, Water, 40, pp. 278-284.

Wang, S., Boyjoo, Y., Choueib, A. \& Zhu, Z.H. (2005). Removal of dyes from aqueous solutionusing fly ash and red mud, Water Research, 39, pp. 129-138.

Yang, Z., Zhang, Z., Chai, L., Wang, Y., Liu, Y. \& Xiao, R. (2016). Bioleaching remediation of heavy metal-contaminated soils using Burkholderia sp. Z-90, Journal of Hazardous Materials, 301, pp. 145-152.

Zhu, C.S., Wang, L.P. \& Chen, W.B. (2009). Removal of Cu (II) from aqueous solution by agricultural by-product: Peanut hull, Journal of Hazardous Materials, 168, pp. 739-746. 